\title{
Services as the Quid Pro Quo for a Safeguards Code
}

\author{
Bernard M. Hoekman
}

\begin{abstract}
$\mathfrak{d}^{1}$ HE General Agreement on Tariffs and Trade (GATT), like other international agreements, is replete with 'safeguards' or 'escape clauses'.' The main one, set out in Article XIX, permits the introduction of emergency protection against a sudden surge of imports of a particular product. But the provision has proved to be inadequate and is not invoked very often. Governments have found 'informal' discriminatory arrangements, negotiated bilaterally outside the GATT system, a more attractive alternative.

For developing countries, in particular, the reform of the multilateral safeguard system is of great importance. ${ }^{2}$ Indeed, it can be argued that the lack of effective discipline on emergency protection undermines considerably the value of GATT membership for developing countries. The failure of the talks on a new safeguards code during the Tokyo Round of multilateral trade negotiations, conducted under the auspices of the GATT in 1973-79, certainly devalued the achievements of that round. What is at stake for developing countries is access to markets of developed countries. As the adherence to the GATT principle of non-discrimination diminishes, uncertainty regarding future access to markets increases, specialization according to comparative advantage is made more difficult and production and consumption decisions become distorted.

In September 1986, at Punta del Este, the member countries of the GATT agreed to launch a new round of multilateral trade negotiations, the Uruguay Round. The agenda covers familiar topics such as trade in manufactured and agricultural products, 'unfinished business' from the Tokyo Round negotiations (including safeguards) and new topics such as trade in services, intellectual property rights and trade-related investment measures. The Uruguay Round negotiations offer another chance to reach an effective agreement regarding the imposition of emergency protection. It is unlikely, however, that developing countries, which have the most to gain from multilateral discipline on safeguard actions, will be able to secure an agreement along the lines they would prefer if
\end{abstract}

BERNARD M. HOEKMAN: a Research Fellow at the Institute of Public Policy Studies, University of Michigan, Ann Arbor, in the United States of America; co-author of Assessment of the GATT Codes on Non-tariff Measures (1988). 
trade-offs are to be limited to the safeguards issue. A case is made here that linking negotiations on different issues may be a productive strategy for all the countries concerned. For linkage to be feasible the issue chosen must be one on which developing countries can offer 'concessions'. In practice, this will probably mean that developing countries will have to liberalize access to their markets for goods, services or both. For a number of procedural reasons explained below, linkage between services and safeguards appears to offer the greatest potential for mutual gains. The argument for linkage in the Uruguay Round negotiations, however, is quite general.

\section{GATT RULES ON EMERGENCY PROTECTION AND THE INCENTIVES TO CIRCUMVENT THEM}

Article XIX of the GATT allows emergency action to be taken against imports of a particular product which are deemed to be causing, or threatening to cause, 'serious injury' to domestic producers of like or directly competitive products. While permitting safeguard actions, Article XIX specifies that certain conditions must be satisfied. Thus there are rules relating to the establishment of 'cause' and 'serious injury' as criteria for the introduction of emergency protection. Article XIX also gives affected exporting countries the right to retaliate against the country imposing protective measures if compensation by that country is not forthcoming or is deemed to be inadequate. Finally, it is generally accepted that safeguard actions under Article XIX should be implemented on a non-discriminatory basis. $^{3}$

It is beyond the scope of this article to discuss at length the reasons why safeguard protection is felt to be necessary by an imposing country. Essentially, though, it reflects an unwillingness on the part of developed countries to adjust to shifts in comparative advantage. In this connection, the Australian economist W. M. Corden has hypothesized: 'Policy reactions to market disturbances are frequently influenced or governed by implicit values that could be summarized in a "conservative social welfare function"., " The distinguishing characteristic of a conservative-social-welfare function is that real income losses of any significant group in a society are to be avoided. Governments thus intervene in response to market disturbances in order to protect existing real incomes.

Since the early 1970s safeguard actions have increasingly been taken through 'voluntary' export-restraint agreements (VERs) and other 'grey area' measures outside the purview of the GATT. ${ }^{5}$ One of the objectives of the Tokyo Round negotiations was to develop a safeguard code on emergency protection, elaborating Article XIX, which would prevent countries from circumventing the multilateral discipline and transparency rules of the GATT. While the Tokyo Round deliberations resulted in agreements (codes) on several issues, most 
notably on a range of non-tariff measures, a safeguards agreement proved impossible to negotiate, implying that the status quo was preferred by at least one major country (or bloc) over any proposed agreement. ${ }^{6}$ In order to understand the failure of the negotiations, therefore, it is necessary to assess the 'value' of the status quo, for any safeguards agreement will have to improve on it for all parties concerned. In large part, this entails investigating the incentives to circumvent GATT rules on the imposition of emergency protection - that is, to use VERs and other 'grey area' measures. ${ }^{7}$

Three aspects of Article XIX may explain the widespread use of measures that circumvent the GATT. These are the remedy allowed (that is, the type of protection that may be imposed), the affected party's right to retaliate (the 'compensation' question) and the need to satisfy preconditions such as 'cause' and 'injury'. The last aspect is obvious. Since the use of VERs is not contingent on the satisfaction of prerequisites they are easier for importers to impose/ negotiate. The remedy and compensation issues are related. The former does not concern the instrument of protection, for Article XIX permits the imposition of tariffs or quantitative restrictions. An obligation to use tariff protection cannot therefore be an issue. ${ }^{8}$ What is felt by importers to be a constraint is the widely-held perception that safeguard actions should be non-discriminatory. ${ }^{9}$ This is what makes retaliation/compensation a constraint. A preference for selective measures such as VERs can be explained by recognizing that they allow a country to avoid the 'compensation-retaliation bill' of a non-discriminatory action, while at the same time offering built-in compensation to affected exporters by permitting them to garner the quota rents.

Although this justification for selectivity may seem intuitive, on reflection it is not very convincing, in large part because protection applied on a selective basis is rarely effective. As long as there exist competitive sources of supply and protection is seriously sought, one VER almost invariably leads to a series of such arrangements. The ineffectiveness of selective protection has been demonstrated convincingly in the literature on the subject. ${ }^{10}$ In those cases where protection is seriously felt to be necessary, it will usually have to be extended into a global system. Textiles, television receivers and steel are well-known examples where this has occurred. From an economic perspective, however, selective protection (whether or not it eventually leads to a global system of restrictions) will usually be more costly than protection which is applied on a non-discriminatory basis. This is because of the distortions associated with selective actions which do not occur if the action is truly global from the very start.

Given the ineffectiveness and high cost of selective protection, the demonstrated preference for selectivity on the part of importing countries must have mainly non-economic foundations. Possible arguments for being able to impose protection on a selective basis include the following. 
One possibility is that governments are well aware of the ineffectiveness of discriminatory measures and that is precisely why they are willing to impose them. In this way they keep both domestic and foreign affected firms relatively happy. While the necessity for the parties involved to have differing information makes this a rather unlikely explanation, there could be some relevance to this argument, depending on the relative power of the domestic industry.

Another possibility, related in some sense to the first one, is that governments do not wish to be perceived as being (too) protectionist. It may well be that it is easier to defend a limited protectionist action to other countries and/or domestic groups who oppose the protection, while at the same time satisfying (albeit imperfectly) the relevant domestic industry.

Finally, selective action allows one to exempt allies and 'innocent' parties which one does not want to subject to 'unfriendly' measures. For example, selective actions have been justified by pointing out that global actions would affect beneficiaries of preferential tariff schemes.

More generally, the preference for selectivity may be explained in part by a growing desire to turn away from multilateralism and towards bilateralism. In the United States this trend towards bilateralism is reflected in the calls for 'a level playing field', bilaterally balanced trade and 'reciprocity'.

\section{TOWARDS A SAFEGUARDS AGREEMENT}

Ideally, developing countries (and many developed countries for that matter) want a safeguard code on emergency protection to include as major elements non-discrimination, compensation and criteria for determining when action can be taken. Indeed, the elements of an 'optimal' agreement for developing countries are likely to resemble Article XIX closely. The American economist Alan Deardorff has proposed elements of a safeguards code which may be considered to be representative of the type of agreement many developing countries might seek. ${ }^{11}$ He proposes that the remedy in a safeguard action should be a temporary global quota set at a level no less than some base-year level of imports (prior to injury). Quotas would be allocated to all exporting countries - thereby ensuring, to a greater or lesser extent, both non-discrimination and compensation. Furthermore, quotas would be transferable between countries; that is, they would be globally marketable. This would ensure that trade and specialization followed comparative advantage since there would be only one quota premium (equivalent to an MFN tariff).

In economic terms, a safeguards agreement along these lines would be superior to the status quo (VERs) for all parties. Developing countries as a group would gain since, in addition to the procedural requirements of an agreement (relating to 
issues such as criteria for action, transparency and the duration of safeguard protection), non-discriminatory safeguard actions and tradeable quotas imply a substantial reduction in uncertainty regarding future market access, while still ensuring some degree of compensation. Developed countries also would gain because safeguard protection would be effective and less costly than global systems of bilateral export restraints. In general, safeguard actions taken in this way would avoid the distortions due to the initial imposition of the VER (such as trans-shipment, false certificates of origin and incentives to relocate production facilities) and, too, the distortions due to the gradual cartelization of the world market which freezes a certain pattern of production and trade.

It should be noted that Professor Deardorff's proposal improves on those made during the Tokyo Round negotiations. ${ }^{12}$ Proposals for a safeguards code during (and after) the Tokyo Round talks either incorporated provisions for the selective application of emergency protection or rejected selectivity completely. Those who rejected selectivity, however, did not offer anything substantial to those in favour of it to induce them to drop their demands. Conversely, those arguing for selectivity often offered 'packages' that were worse for exporters than the status quo. This was especially true of proposals incorporating some kind of 'consensual' selectivity, where the compensation requirement would be waived for those countries imposing safeguard protection in conformity with the procedural requirements of the code. Such proposals offer few incentives for exporters. Those countries most likely to be subjected to safeguard protection would lose their compensation, while those likely to be excluded from an action would neither gain nor lose. The main advantage of such a code is the discipline it would presumably impose regarding the introduction of emergency protection. Quite likely this was (and is) not a sufficient inducement for exporters.

These kinds of problems also exist with respect to achieving acceptance in the Uruguay Round negotiations of a safeguards agreement along the lines discussed above. What are the incentives for importers to sign and abide by such an agreement, given the preference they continue to show for selective actions outside the GATT? One cannot rely on the hope that importing countries have come to realize that non-discrimination is in their best interests. It is noteworthy, however, that there are some signs that the preference for selective actions on the part of the European Community may have weakened. Indeed, it is possible that the Community will accept a non-discriminatory agreement at the end of the Uruguay Round negotiations. ${ }^{13}$ But even if this did prove to be the case, it is not likely that the Community will drop its insistence on selectivity without demanding something else in return. Also, it is not unlikely that the United States will push for a selective agreement of some kind. ${ }^{14}$ Even if all countries were to agree on non-discriminatory application of emergency protection, another problem is that some industrialized countries may push for an agreement without a compensation requirement. 
It is by no means certain that developing countries will be able to achieve a safeguards agreement of the kind they want during the Uruguay Round negotiations. This holds especially if negotiations remain limited to bargaining on the safeguards issue only, for concessions can only be made with respect to selectivity or compensation. But weakening on either of these elements could easily lead to an outcome worse than the status quo for many developing countries. ${ }^{15} \mathrm{I}$ believe there is a case for attempting to bring in other issues - that is, for linking negotiations on different areas. In general, linkage may open up the possibility of agreement where there was none before or it may expand the number of feasible agreements. In either case all parties are made better off. Thus a safeguards agreement of the type preferred by developing countries might become possible if the safeguard discussions were combined (linked) with another issue in such a way that what was 'lost' by a country on one issue was compensated by 'gains' on the other issue. It is important to note that linkage not only may make such an agreement feasible; it can also help to ensure that countries abide by the agreement. This is because, by definition, the costs of reneging increase for all participants since they have more to lose if the agreement breaks down.

The problem, then, is to identify possible issues which might be linked to the safeguard talks. Feasible issues must meet a number of criteria. The major countries involved in both discussions should be the same and they should perceive their interests to be opposed on both issues. Furthermore, the issues should offer sufficient scope for trade-offs. One issue which meets these criteria is access to the markets of developing countries. That is to say, the liberalization of trade regimes in developing countries could be linked to the safeguard discussions. The same players are involved in these issues, their perceived interests diverge on both issues and there certainty appears to be sufficient scope for trade-offs. Issues such as subsidies or agricultural trade do not meet the necessary conditions, for the underlying conflicts are mainly between developed countries.

'Liberalization' is usually taken to refer to trade in goods. For the first time, however, services and trade-related investment measures have been included on the agenda of a GATT round, which means that the focus could be on trade or investment in goods, services or both. There would be a number of practical difficulties with an attempt to link safeguards and developing-country liberalization of trade in goods. ${ }^{16}$ First, there would be legal difficulties, for developing countries have formally been accorded 'special and differential' treatment in Part IV of the GATT, dealing with trade and development. Although this may not have had much effect in practice, it has been codified into the GATT and will be very difficult to alter. This problem does not arise with services or trade-related investment since, for the most part, they are not covered by the GATT. A second and related argument is that the agenda for the Uruguay Round 
negotiations has already been set. While it does include topics such as trade in services and trade-related investment measures, it does not include developingcountry trade regimes. ${ }^{17}$ Since it proved to be very difficult for the GATT Contracting Parties to agree on the agenda for the Uruguay Round negotiations, there are good reasons for accepting the agenda as given. Third, there exist a multitude of preferential tariff schemes affecting trade in goods, which could complicate the discussions. This is not the case for services or trade-related investment which essentially have no history in the GATT.

Of the issues on the Uruguay Round agenda, services appear to offer the greatest scope for fruitful linkage with safeguards. Thus, for example, it is important to note that there are powerful interest groups in the developed countries (especially the United States) which want to see progress made on services. ${ }^{18}$ Conversely, interest groups in developing countries associated with service industries may be weaker on average than those associated with importcompeting goods industries, given that the latter have a vested interest in maintaining existing protection and therefore may be better organized. Accordingly, there may be greater scope for an agreement on services than for liberalization of trade and investment in goods in developing countries. Furthermore, and related to the previous argument, it may be that the gains from liberalizing trade in services are greater than for trade in goods. This is because access to foreign services is often blocked completely, unlike access to foreign goods. In conjunction with the fact that trade in services predominantly concerns trade in intermediate inputs, the domestic forces favouring liberalization in services may be relatively strong.

Perhaps the most important argument for focussing on liberalization of trade in services is that an implicit linkage between services and other issues on the Uruguay Round agenda already exists. Thus, for example, it appears very likely that if the United States feels that negotiations on services have not been fruitful, it will reconsider agreements reached on other issues. ${ }^{19}$ In practice, this is likely to imply unilateral withdrawal by the United States of 'concessions' made on trade in goods, which could be highly detrimental to developing-country interests. A productive strategy on the part of the developing countries would be to recognize this implicit linkage at the outset and attempt to influence the choice of issues to be linked. The remainder of this article outlines some of the arguments that could in principle be put forward by developing countries against participating in the creation of a 'general agreement on trade in services'. I argue that such an agreement could benefit developing countries as much as it could developed countries. Thus a linkage between services and safeguards might enable developing countries to get something for (almost) nothing. Even if this were not the case, the inclusion of services might prove worthwhile if it led to effective multilateral discipline on safeguard action. 
COSTS AND BENEFITS OF MULTILATERAL RULES FOR TRADE IN SERVICES

The push by the major developed countries, particularly the United States, to reach a multilateral agreement on trade in services has not met with great enthusiasm in developing countries. As Rodney de C. Grey, head of the Canadian delegation to the Tokyo Round negotiations, has noted, the services proposal 'must have very little appeal to developing countries. . . As they will see it, the fully industrialized and service economies of the North are trying to rework the GATT bargain, so as to secure new scope either for restricting imports of goods or for obtaining new rights for markets in the South.' ${ }^{20}$ Perceptions of this kind led to services being put on a separate track in the Uruguay Round negotiations. That is to say, the negotiations on services do not formally function under the aegis of the GATT, although GATT procedures and practices are to be followed. ${ }^{21}$ Services are nevertheless an integral part of the Uruguay Round talks, given that the Group of Negotiations on Services reports to the Trade Negotiations Committee and has access to the GATT Secretariat for administrative and analytical support.

It should be emphasized that services are not a North-South issue in the sense of the North standing to gain at the expense of the South. Nor are they a zero-sum game. Who gains and who loses will be determined at a very disaggregated level. Many developing countries are net exporters of services and, although their comparative advantage often lies in labour-intensive services, many services are in fact labour intensive. The main issue, then, is to make sure that those services are included in the negotiations.

An important and frequently used economic argument against the liberalization of trade and investment in services is the infant-industry argument. The issue that needs to be considered is to what extent, if any, the fact that services differ from goods alters the rather stringent conditions which have to be met in order for infant-industry protection to be optimal (or even beneficial). In general, for infant-industry protection to be justified on economic grounds the protected industry must be subject to a short-run cost disadvantage, possibly due to (or in conjunction with) the existence of non-capturable externalities. The protection must have the effect of neutralizing the externality and must only be necessary for the start-up period of the industry. Sources of the externality may be the inappropriability of the necessary technology or 'know-how' which may include the costs of training workers or various market imperfections (in information or capital markets). There does not seem to be anything inherent in the general characteristics of most service industries that diminishes the relevance of the existing literature on infant-industry protection. Thus the general presumption exists that such protection is often inefficient. ${ }^{22}$ Indeed, there may be even less of a rationale for infant-industry protection of many service industries than there is 
for goods industries. This holds especially for what have been called 'demanderlocated services' - that is, services which require the provider to move to the location of the demander. ${ }^{23}$ There is some evidence that often the best way to develop an efficient indigenous (demander-located) service industry is to encourage foreign direct investment. This is especially true for those services where technologies can only be acquired 'by doing'. ${ }^{24}$ In such services, 'turn-key' investment projects are not usually possible, given that the services involved are not tradeable at arm's length. Traditional infant-industry protection may then have very little beneficial effect.

Another possible argument against liberalization is related to the question of comparative advantage. It may be feared that liberalization will lead to balance-ofpayments problems. The implicit assumptions are that most tradeable services are relatively capital intensive and that developing countries are relatively well endowed with (unskilled) labour. After liberalization, due to relatively costly home production of the capital-intensive services, net imports of services would be expected to increase, worsening the current account and making foreignexchange constraints more binding. While this may be perceived as a problem, it is not justifiable from an economic point of view. Although there may be adjustment costs, there is a presumption that domestic welfare would increase in the same way as for the liberalization of trade in goods. In fact, welfare gains may be greater with respect to services, for in general a large proportion of services are intermediate inputs. As the costs of intermediates are reduced, production (and exports) should increase. Also, to the extent that service outputs are nontradeable, allowing service-related foreign direct investment to occur will usually entail increased employment of domestic factors of production. In any event, to the extent that balance-of-payments problems occur as a result of liberalization, it could be agreed that lending by the International Monetary Fund or the World Bank would be made available.

Service industries are often more heavily regulated than other parts of the economy. While the arguments against liberalization discussed above were economic in nature, more often than not arguments against reducing the scope for discretionary government behaviour are non-economic. In general, the often extensive regulation of service industries is based on safeguarding the "national interest'. How this is defined is, of course, a sovereign matter. But, as argued by the Australian economist Gary Sampson, it should be realized that protection, however justified, has economy-wide implications. ${ }^{25}$ In general, for good decision making to occur, it is necessary for information on these implications to be supplied and taken into consideration in the decision-making process. At present, this is not done enough, in either developing or developed countries. ${ }^{26}$

While much empirical work remains to be done, the arguments against creating a multilateral agreement on trade in services do not seem to be compelling. Developing countries potentially stand to gain through the transfer of technology, 
the lower cost of inputs and final services, the increased net exports of those services in which they have a comparative advantage and, finally, being able to consume a greater variety of services. To be sure, inefficient firms will suffer and adjustment costs may be high for some industries in some countries. The key issue is the extent to which the benefits outweigh the costs. The argument made here is that the benefit-cost ratio may often by positive. In general, this has been the experience of the developed countries. In any case, the net benefits presumably will be greater if 'concessions' on services help to achieve an agreement on safeguards. Arguably, for many developing countries, safeguards are a more important issue than services.

\section{CONCLUDING COMMENTS}

The premise of this article is that the Uruguay Round negotiations offer a unique opportunity to deal with the problem of safeguard protection, but that the negotiations may have to be broadened to include seemingly unrelated issues. It should be emphasized that linkage may not prove to be necessary. If it has become sufficiently clear since the Tokyo Round negotiations that the economic incentives for importing countries to pursue selective safeguard actions are minimal and this leads to sufficient pressure (domestic and international) on governments to abstain from them, it may be that proposals which would benefit all parties in economic terms have become feasible. Given that the political preference displayed for selectivity and discretion in trade policy shows few signs of abating, however, developing countries may have to show a willingness to 'buy' the type of safeguards agreement they want. I have argued that one way in which they may be able to do so is by participating in the negotiations on services and linking the two issues. As noted above, it is likely in any case that services will be linked to the rest of the negotiations. Thus an implicit linkage already exists. The question then arises whether linkage should be formalized explicitly. I do not believe that this is required. All that is necessary is that participants are aware that, at some point, linkages will be required and that they agree on the issues to be linked. At what point in the negotiations linkage should occur is best left to the negotiators.

It should be noted that there is likely to be a general need for linkages in the Uruguay Round negotiations if they are to be a success. In large part this is because the United States, with its huge and persistent trade deficit, will not be willing to offer concessions that are not matched by those of other countries. Although present current-account disequilibria have macro-economic causes and need macro-economic remedies, they do have implications for GATT negotiations. Arguably, the main task of the negotiatiors is to prevent a further closing of developed-country markets (through a 'standstill and rollback'). This will require the more advanced developing countries to liberalize access to their own markets. 
In closing, I can do no better than quote from the address of Paul Volcker, the former chairman of the Federal Reserve Board in the United States, on the occasion of the GATT's fortieth anniversary celebration last November. 'Obviously, instead of growing trade frictions there should be the makings in this area [market access] of a constructive international bargain - liberalization of trading practices by the middle-income developing countries (and the newly industrialized countries) while the industrialized world provides greater assurance that its markets will remain open. ${ }^{27}$ This article has proposed possible elements of one such bargain. Many others are also possible and may prove to be more feasible. The point to be made is that negotiators will have to be creative in their attempts to achieve 'constructive international bargains'.

1. This article has greatly benefited from comments on earlier drafts from Robert M. Stern and Alan V. Deardorff. Financial assistance was provided by a grant from the Ford Foundation for a programme of research on trade policy at the University of Michigan.

2. As used here, the term 'developing countries' should be understood to include the newly industrializing countries. In practice, it is the latter group of countries that is most affected by safeguard actions, but the issue is important for all developing countries. In terms of the Uruguay Round negotiations, however, it is clear that the more advanced developing countries will have to take a leadership role.

3. See Ernst-Ulrich Petersmann, 'Economic, Legal and Political Functions of the Principle of Non-discrimination', The World Economy, London, March 1986.

4. W.M. Corden, 'Policies Towards Market Disturbance', in Richard H. Snape (ed.), Issues in World Trade Policy: GATT at the Crossroads (London: Macmillan, 1986) pp. 121-40. The concept of a conservative-social-welfare function was first described in Corden. Trade Policy and Economic Welfare (Oxford: Clarendon Press, 1974). Use was made of the concept in Patrick Messerlin, 'The Political Economy of Protection: the Bureaucratic Case', Weltwirtschaftliches Archiv, Kiel, Vol. 117, No. 3, 1981, pp. 469-96, and Alan V. Deardorff, 'Safeguards Policy and the Conservative Social Welfare Function', in Henryk Kierzkowski (ed.), Protection and Competition in International Trade (Oxford: Basil Blackwell, 1987).

5. See Gary Sampson, 'Safeguards', in J. Michael Finger and Andrzej Olechowski (eds), The Uruguay Round: a Handbook on the Multilateral Trade Negotiations (Washington: World Bank, 1987).

6. For a general discussion of the negotiations, see Leslie A. Glick, Multilateral Trade Negotiations: World Trade after the Tokyo Round (Totowa, New Jersey: Rowman and Allanheld, 1984), and Gilbert R. Winham, International Trade and the Tokyo Round Negotiation (Princeton: Princeton University Press, 1986). Excellent analyses that focus in part on the safeguards issue are Hugh Corbet, 'On the Importance of Being Earnest about Further GATT Negotiations', The World Economy, September 1979, pp. 319-41, and Victoria Curzon Price, 'Surplus Capacity and What the Tokyo Round Failed to Settle', The World Economy, September 1979, pp. 305-18. An evaluation of the operation of the Tokyo Round codes is contained in Robert M. Stern, John H. Jackson and Bernard M. Hoekman, Assessment of the GATT Codes on Non-tariff Measures, Thames Essay No. 57 (Aldershot, Brookfield and Sydney: Gower, for the Trade Policy Research Centre, 1988).

7. The following discussion is based on a much more extensive analysis in Hoekman, 'The Uruguay Round of Multilateral Trade Negotiations: Investigating the Scope for Agreement', mimeograph, University of Michigan, 1988.

8. See Jackson, The Role of GATT in Monitoring and Promoting Adjustment; the Safeguards System, Research Seminar in International Economics Discussion Paper No. 170 (Ann Arbor: University of Michigan, 1986). 
9. The legal arguments for non-discriminatory safeguard actions, while strong, are not completely unambiguous. See ibid.

10. See, for example, the following studies: Robert E. Baldwin, The Inefficacy of Trade Policy, Essays in International Finance No. 150 (Princeton: International Finance Section, Department of Economics, Princeton University, 1982); Baldwin and Richard Green, 'The Effects of Protection on Domestic Output', mimeograph, University of Wisconsin, Madison, 1987; Gary Clyde Hufbauer, Diane T. Berliner and Kimberly Ann Elliot, Trade Protection in the United States: 31 Case Studies (Washington: Institute for International Economics, 1986); Helen Hughes and Anne O. Krueger, 'Effects of Protection in Developed Countries on Developing Countries' Exports of Manufactures', in Baldwin and Krueger (eds), The Structure and Evolution of Recent US Trade Policy (Chicago: University of Chicago Press, for the National Bureau of Economic Research, 1984); and David B. Yoffie, Power and Protectionism: Strategies of the Newly Industrializing Countries (New York: Columbia University Press, 1983).

11. Deardorff, loc. cit. A proposal of this type is consistent with the one put forward in May 1987 to the Uruguay Round negotiating group on safeguards by a group of countries comprising Australia, Hong Kong, the Republic of Korea, New Zealand and Singapore.

12. A detailed analysis of the failure of Tokyo Round talks on safeguards is beyond the scope of this article. The following discussion is based on Hoekman, op. cit.

13. This statement is based on discussions with European Community trade officials. See also The Economist, London, 18 July 1987 , p. 71.

14. According to some trade officials in the United States, this cannot be ruled out, given the present mood of Congress.

15. For a detailed discussion of the issues raised here, see Hoekman, op. cit.

16. The following arguments should not be taken to imply that there is not a strong case to be made for (unilateral) liberalization of trade regimes by developing countries. An argument along these lines in the context of GATT negotiations is made in Martin Wolf, 'Two-edged Sword: Demands of Developing Countries and the Trading System', in Jagdish N. Bhagwati and John Gerard Ruggie (eds), Power, Passions and Purpose: Prospects for North-South Negotiations (Cambridge: Massachusetts: MIT Press, 1984) pp. 201-30.

17. The Uruguay Round agenda covers fifteen topics: tariffs, non-tariff measures, natural resource-based products, textiles and clothing, agriculture, tropical products, GATT articles, MTN agreements and arrangements, safeguards, subsidies and countervailing measures, trade-related aspects of intellectual property rights, including trade in counterfeit goods, trade-related investment measures, dispute settlement, functioning of the GATT system and, finally, services.

18. In itself, as noted in Wolf, loc. cit., 'the intensity of American interest can prove tactically useful since developing countries should be able to obtain something in return for a willingness to discuss the issue' (p. 222).

19. See, for example, Jeffrey Ryser and John Templeman, 'In Uruguay, General Disagreement on Tariffs and Trade', Business Week, New York, 6 October 1986, p. 31.

20. Rodney de C. Grey, 'Negotiating about Trade and Investment in Services', in Stern (ed.), Trade and Investment in Services: Canada/US Perspectives (Toronto: University of Toronto Press, for the Ontario Economic Council, 1985).

21. This reflects a compromise reached between those GATT member countries which supported bringing services into the Uruguay Round negotiations and those countries (led by Brazil and India) which opposed any discussion of extending the GATT to new areas.

22. The degree of inefficiency is a function of the instrument of protection. Thus, for example, tariffs or import quotas are usually less inefficient than subsidies since they are more distortionary.

23. Stern and Hoekman, 'Issues and Data Needs for GATT Negotiations on Services', The World Economy, March 1987, pp. 39-60. Examples of demander-located services include many professional services, especially those where face-to-face contact is important.

24. See Ronald K. Shelp, John C. Stephenson, Nancy S. Truitt and Bernard Wasow, Service Industries and Economic Development: Case Studies in Technology Transfer (New York: Praeger, 1984). 
25. Sampson, 'Developing Countries and the Liberalization of Trade in Services', mimeograph, 1987.

26. As discussed in, for example, Stern and Hoekman, loc. cit., data problems severely hamper research on the services sector. But the kind of information required is often not even sought. The problem, then, is as much one of demand as of supply. The general argument applies as much to goods as it does to services. In this connection, see Samuel Laird and Sampson, 'Case for Evaluating Protection in an Economy-wide Perspective', The World Economy, June 1987, pp. 177-92.

27. Paul Volcker, 'GATT under Stress: Is There Life after 40?', address at the fortieth anniversary celebration of the GATT, Geneva, 30 November 1987.

\section{$+\infty$ \\ James Baker on a New Trade Policy Strategy for the United States}

EXTRACT from a speech given by James A. Baker, Secretary of the United States Treasury, to the Canadian Importers Association, Toronto, on 22 June 1988:

' The free trade agreement now being considered by the legislatures of Canada and the United Statesl can serve not only as a pattern for future bilateral agreements but also as a catalyst for action on the multilateral front. . .

'Many in the United States Congress are frustrated by the persistent trade imbalance and are trying to legislate the problem away. One of their approaches is to return to straightforward legislative protection for industries, for example through direct restrictions on imports. Other nations are relying on similar barriers, frequently dressed up with local political justifications. A second counter-productive approach, perhaps more popular, has been termed "process protectionism". This type of legislation tries to conceal itself as nothing more than seemingly modest adjustments in trade laws. But each tightening twist of law chokes off trade a little more, with little or no regard for GATT rules, international . standards or the likelihood of triggering retaliatory trade wars. . .

'There is, however, an alternative approach to the future. This approach is idealistic in aim, but realistic and often incremental in method. It seeks to move nations toward a more open trading system through a strategy of consistent, complimentary and reinforcing actions on various international fronts, bilateral and multilateral. As some of these actions bear fruit, they should enhance domestic political support for other actions.

'This is the approach embodied in the Canada-US Free Trade Agreement. While the international trading system has been subject to increasing stress and strain, the Canadian-US economic relationship has been growing and strengthening. Indeed, after over a century of failed efforts, our governments have a sterling opportunity to complete a North American Economic Accord. . .

'[The agreement] accommodates and enhances future trade-liberalization efforts in six ways. 
'First, the agreement respects the GATT and is careful not to undermine the successes of the multilateral approach. Canada and the United States are lowering barriers between themselves, not raising barriers to others. We are seeking a healthy, dynamic linkage between bilateral and multilateral initiatives so as to prod and reinforce the GATT.

'Second, the Canada-US agreement extends the reach of an open cooperative system by negotiating solutions in the areas of services, investment and technology - while respecting national sovereignty. (These arrangements demonstrate what can be achieved and offer conceptual approaches to which others may turn.)

'Third, we have lowered the cost of initiating international liberalization in these new areas by breaking ground with only one nation at a time. When more nations are involved, it is often harder to arrange a satisfactory compromise.

'Fourth, the rewards of this agreement offer an incentive to other governments. If possible, we hope this follow-up liberalization will occur in the Uruguay Round. If not, we might be willing to explore a "market liberalization club" approach, through minilateral arrangements or a series of bilateral agreements. In this fashion, North America can build steady momentum for more open and efficient markets.

'Fifth, this agreement is also a lever to achieve more open trade. Other nations are forced to recognize that we will devise ways to expand trade - with or without them. If they choose not to open their markets, they will not reap the benefits. By employing this lever together, the United States and Canada may be able to dislodge obstacles in special areas of common concern - such as agriculture.

'Sixth, this Canadian-US accord could prove to be an attractive counterweight to protectionism in both our countries. It attracts those who want government to foster growth and opportunity by breaking down obstacles to the achievement of fair competition, not by creating barriers to protect special interests. . .

'We need to enhance the resiliency of the trading system by promoting liberalization on a number of fronts. While we normally associate a liberal trading system with multilateralism - bilateral or minilateral regimes may also help move the world toward a more open system. Indeed, different agreements may be complementary, each fitting a special situation and together creating a liberalized network of mutually reinforcing systems. If activity on one frontier of trade negotiation slows, we may be able to maintain momentum and achieve solutions worthy of imitation through other agreements. If all nations are not ready to liberalize trade, we will begin with those that are and build on that success.

'The free trade agreement provides economic opportunities for both Americans and Canadians - and could be the catalyst for a new trade policy strategy. The inquiries it already has elicited for similar agreements are encouraging. This interest gives both our countries an opportunity to set trade policy on a creative, positive and pragmatic international course - one that will benefit everyone associated with it.' 